Iryna Davydova,

PhD (Candidate of Legal Sciences), associate professor, Department of Civil Law, National University "Odessa Law Academy”, 23, Fontanska Doroha Str., Odesa, Ukraine

\title{
DOES PRACTICAL COMPONENT OF EDUCATIONAL PROCESS IMPROVE PROFESSIONAL COMPETENCE OF FUTURE LAWYERS?
}

The article is dedicated to the study of the application of innovative methods in the process of students training, namely: the role and place of the practical component in the formation of professional competence of future lawyers. It has been found that educational programs should be focused on the broader professional competences (functions) of future lawyers, namely epistemological, communicative, functional, personal, which play the main forming role in terms of acquisition of professional skills by the students and the development of relevant (professional) competence. The significance of the practical component in the training process, implies that there is a possibility to use training time for group classes, where students can discuss the content of the lecture, test their knowledge and interact in practice, has been emphasized. An experimental variant of the educational process, with a wide implementation of the practical component focused on the formation of leading competencies of future lawyers, has been developed. On the basis of the created methods of professional competences assessment, positive results of the applied technology of training have been obtained: there is a substantial increase in the level of competence of future lawyers. According to the results of the approbation, concrete proposals have been made regarding the modern reform of the educational process in the field of professional training of lawyers by introducing new forms and methods of active training with the widespread use of the practical component aimed at the formation of professional competence of future experts.

Keywords: legal education, renewal, educational process, methods of active learning, professional competence.

\section{Introduction}

The relevance of the research is determined by social-economic and political changes in the society, strengthening of the statehood of Ukraine, its entry into the European world community, which is impossible without the modern reforming of the system of higher education, including increasing the efficiency of the educational process.

The significance and the possibility to apply and use some knowledge in specific spheres of life are coming to the foreground in the process of studying. Education in the field of legal studies today requires students to be vigilant, diligent and hard-working. Therefore, the most requested pedagogical technologies are those which create conditions that increase the analytical skills of students, their independence, initiative, since the key mechanism that triggers the development of the individual is the mechanism of self-organization.

Nowadays, there is an urgent need for the training of lawyers who would have profound knowledge both in the purely legal sciences and those that reflect the current state of the society's development, namely: information technologies, economics, political science, public administration, etc.

The abovementioned causes the necessity of conducting relevant research in order to find and develop proposals for the modern reformation of the educational process: the application of innovative methods of active learning, including strengthening the practical component of the educational process and studying its impact on the formation of professional competence of future lawyers.

Multi-aspect challenges of higher legal education, peculiarities, and effectiveness of teaching technologies, their modern reforming are regarded by lawyers, practitioners in various branches of law, as well as by experts in pedagogy, legal psychology, economics, public administration, etc.

The multi-method researches which partly concern the suggested topic were carried out by O. Kotikova in relation to the characteristics of the theoretical and methodological foundations of psychological and pedagogical training of future lawyers [1].

Professor V. Sushchenko suggested the following criteria for improving the state of higher legal education: the level of general culture combined with knowledge of legal theory and practice in the system of training; in the field of improving the educational process in law schools - ... reforming the current evaluation process of the quality of mastering professional knowledge, skills, skills, etc. [2].

The issue of the development of professional competence of future lawyers was considered by I. Ivashkevich in his thesis, where the professional competence of a lawyer is defined as a system of personality characteristics, on which the success of the individual's realization of both social and personally meaningful functions depends. Professional competence is considered as integrative characteristics, which indicate the level of readiness of a specialist to perform professional activity, and con- 
sists of certain components (motivation-target, cognitive, social, axiological), substructural elements, basic functions of lawyers (predictive, humanistic, design) [3].

In addition, the technology of 'flipped learning', which was revolutionary in the field of higher education, was suggested by Dr. Mazur and made him the first winner of the Minerva Award. His achievement was peer instruction which is a pedagogical model in which lectures are replaced by discussion of specific practical tasks in the audience [4].

The technology of Flipped Learning was taught by Chemistry teachers Aaron Sams and Jonathan Bergmann (USA). In their book "Flip Your Classroom: Reach Every Student in Every Class Every Day", they talk about the features of this technology and its capabilities. In 2010, Clintondale High School in Detroit, USA, became the first 'flipped school', which completely switched to the principle of 'inverted learning'.

At present, the task of higher education regarding the professional training of lawyers significantly changes, which is connected with the restructuring of the traditional system of education, the introduction of the latest teaching technologies based on the achievements of psychology and pedagogy, which, in turn, requires special attention within the research

The goal of the research is to analyze the current state of the renewal of legal education, namely, the educational process, to identify problems that arise during the training activities and to develop appropriate suggestions for the modern reforming process of the curriculum in terms of strengthening the practical component, focused on the formation of professional competence in future lawyers (the development of competence), as well as to check them experimentally.

The tasks of the research are:

to determine the role and place of the core competencies of future lawyers in the aspect of their professional skills development (the development of the competence of the lawyer), to identify the leading ones;

to build an experimental version (a training program) of the educational process, where the practical component is focused on the formation of the leading competences of future lawyers;

to build a method of assessment of the level of professional competences and to carry out testing of the suggested educational process.

\section{Research methods}

It is on the basis of seminars that an experimental version of the educational process, where the practical component is focused on the formation of the leading competences of future lawyers, has been built. This experimental version was tested at seminars in 4 groups (approximately 20 students in each) for two years (involving about 160 students). After its accomplishment, on the basis of the developed method for evaluating professional competencies, positive results were obtained in improving the quality of mastery of studies, developing students' skills in teamwork, self-education, self-learning, critical thinking, communicative skills, ability to find unconventional solutions to problems.

The methods of active learning with a wide use of the practical component, which is fully focused on the formation of the leading competences of future lawyers, have been experimentally implemented.

This practical testing has been based on the following basic competencies (functions) of future lawyers: epistemological (the availability of certain knowledge necessary for the performance of professional duties, constant updating, improvement), communicative (ability to cooperate, achievement of compromises, agreements), functional (the ability of a person to act, to perform his/her duties on the basis of experience - personal, collective); personal (awareness of the person of his/her destination, self-criticism, ability to self-analysis of his/her professional qualities in order to overcome the negative ones).

The technologies of professional simulation, the solution of specific situations and the active roles enactment were used. These methods became a peculiar polygon, on which students began to form practical components of the professional skills as future law specialists, close to the reality.

The technology of the educational process was completely reoriented from the theoretical presentation by the students of the preliminarily learned material of the seminar in the form of issues on practical formation of the competence of lawyers in the form of forced, evaluated and guided activity of students, which is comparable to the activity of the teacher.

The technological process is built as follows: Establishing a list of competencies for their formation at the seminar - Preparation of algorithms, and necessary actions for achievement at the seminar Drawing up the graphics model of the class.

During the professional simulation, the professional situation taken from real life was selected, an appropriate model was created artificially, which was then transferred to the team of students for direct simulation during the lesson. The purpose of carrying out the professional simulation was the revision of theoretical material, development of skills for generating ideas, ability to analyze and predict, evaluate, show the ability to solve non-standard situations, etc.

Students picked up the specified method of conducting a seminar with animation, actively participated in the simulation, revealed their real state of awareness and understanding of the given material, 'included' additional knowledge from other fields, their professional practical component could be traced and accordingly the goal of the professional simulation was achieved.

The technology of "solution of problematic situations" was applied by the following algorithm: search, development, formulation of a specific situation; goal, rules of the solution of the problem; division of students into groups; analysis and decision-making of the situation by each student individually; intragroup discussion and 
collective decision-making; discussion and formation of the optimal decision based on the group; summing up, discussing rejected options of solving the problem.

The following goals were set at the application of the technology for solving specific situations: forming the ability to make decisions independently, the ability to analyze the situation, mastering creative thinking, developing the ability to distinguish cause and effect relationships.

According to the results of the experimental version of the educational process, with the leading role of the practical component, which is focused on the formation of the competences of future lawyers, a method for evaluating professional competencies was developed.

Thus, every academic year, 4 academic groups of students took part in the training, 3 seminars were conducted in two of these groups with the use of active learning methods: one corresponding technology described above was applied at each seminar. In the other two groups, seminars were conducted using traditional methods of learning. At the abovementioned seminars, students received scores (B) in accordance with the "emergence" (development, demonstration) of a competence expert assessment (EA). The expert assessment was calculated according to the following equation $\mathrm{EA}=\left(\sum /\right.$ Nstud. ) * Kact., where $\sum$ is the sum of all the scores obtained by the students on the specified competencies, Nstud. - the number of students who received a score on the competence, Kact. - the rate of activity of students. Kact. = the number of students who participated in work/total number of students.

The level of self-assessment of students based on the results of the introduction of learning technology is based on the practical component, determined on the basis of oral communication when taking a test in the subject by giving points according to the students' assessment of their levels of mastery of one or another competence - self-assessment (SA). Self-assessment was calculated using the following formula: SA $\Sigma /$ Nstud., where $\Sigma$ is the sum of the points, according to the students' selfassessment on the given competence, Nstud. - the number of students.

\section{Research Results}

In the course of the participation in solving specific situations, the active work of all students who joined the collective, team activity, the leadership qualities of individuals began to emerge, the students already faced a profession-related challenge, for which the teacher had the optimal solution. In connection with this, conclusions about achieving the goal of this technology were made.

The enactment of active roles was the adoption of the solutions by the students in the situation previously prepared by the teacher through its direct enactment. This technology was most actively perceived by the students, especially as part of the course of family relationships. Each participant in the situation experienced the whole process of "communicating in the situation", their complete internal transformation in accordance with the role and general purpose took place. The purpose of this method is as follows: activating the imagination and thinking, using the received information, predicting the development of the situation, demonstration of the personality.

Taking part in the enactment of the active roles, students enjoyed "growing into their roles" as participants in family disputes both in court debates and in extrajudicial conflict resolutions. In these processes, there was an active expression (development) of imagination, thinking, personal uniqueness, improvisation, the atmosphere of openness, satisfaction prevailed in the classroom. Considering this, we believe that the goal was achieved.

According to the results of the practical testing of the experimental version of the educational process, the following results were obtained (presented in Table 1).

The average data characterizing the groups of law students trained according to traditional and active learning methods

\begin{tabular}{|c|c|c|c|c|c|}
\hline \multicolumn{2}{|c|}{} & Epistemological & Communicative & Functional & Personality \\
\hline \multirow{2}{*}{ Traditional method } & Expert assessment & 1.55 & 2.09 & 2.09 & 1.47 \\
\cline { 2 - 6 } & Self-assessment & 1.85 & 3.49 & 3.10 & 2.23 \\
\hline \multirow{2}{*}{ The suggested technique } & Expert assessment & 2.19 & 3.13 & 2.82 & 2.05 \\
\cline { 2 - 6 } & Self-assessment & 2.21 & 4.08 & 3.81 & 4.92 \\
\hline
\end{tabular}

Thus, we clearly see a significant increase in the level of competence of future lawyers due to the introduction of the suggested educational process with the leading role of the practical component (communicative 49\%, epistemological $41 \%$, personality $39 \%$, functional $35 \%$ ).

It should be noted that getting significant positive results, in our opinion, was also possible due to the involvement of a practitioner into the educational process who had participated in resolving disputes in real life, had knowledge about the suggested situations and options for their solution in reality in such methods of active learning.
It emphasizes the need to involve practitioners into the educational process. In connection with this, we offer to consolidate the imperative rule on the minimum number of (in terms of percentage) faculty teachers and lecturers of legal universities.

\section{Discussion}

The entry of Ukraine into the European educational community has actualized the need for introducing new forms of educational process organization, record keeping and knowledge assessment systems. Unfortunately, students often think about the futility of humanitarian 
knowledge, the inability to reconcile it with the future profession.

While exploring the issues of employment of university graduates and increasing their competitiveness in the labor market, professional, psychological training for practical activities in the legal sphere, it should be noted that, according to Mantz Yorke, being employed means to be in a risk zone, to have the ability to work - to be in safety [5]. Therefore, employability is one of the key comprehensive issues of the European Higher Education Area, which is actively considered and undergoing structural reforms [6].

The developers of the White Paper on the Reform of Ukrainian Legal Education came to the conclusion that in most Ukrainian universities ... a complete reorientation of the content and orientation of seminars, which should be focused not on the revision of theoretical material, but on dealing with specially designed practical situations, as close as possible to realities of law enforcement activities [7].

Thus, at the World Economic Forum held in Abu Dhabi, the following abilities which should be developed in the modern world were named among the main characteristics - literacy (basic literacy, ability to count, scientific and cultural literacy); competencies (ability to solve problems, creative approach, etc.); necessary character traits (curiosity, entrepreneurial abilities, ability to work in a team, etc.) [8].

The essence of the concept is as follows: the key skills that determined literacy in the industrial era were reading, writing and arithmetics. In the XXI century, the same emphasis shifts toward the ability to think critically, the ability to interact and communicate, creative approach.

And therefore, nowadays people need to be taught the ability to think, acquire information independently and critically evaluate it, rather than simply accumulate it and memorize.

Approaches to teaching, respectively, also should be changed. Today, school and university students sometimes have much more knowledge in some areas than their teachers due to the Internet and information technology. Therefore, the teachers gradually transform from the transmitters of knowledge into teachers-organizers.

Therefore, the curriculum should be aimed at developing critical thinking, communicative skills, creative ingenuity and interaction skills, since most students are able to build interpersonal relationships. Therefore, the curricula should be oriented towards wider professional competences - the ability to find non-standard solutions to problems, teamwork skills, etc.

Therefore, in order to develop future lawyers' professional competence and appropriate competencies, enhance their employability, the institutions of higher legal education are recommended to develop and implement training programs which would meet the following requirements: 1) to be based on the study and development of core competencies of future lawyers; 2) the lead- ing role should be given to the practical component, which is focused on the formation of these competencies; 3 ) according to the specialization of educational institutions and curricula, the involvement of practitioners of the legal sphere in the educational process (especially seminars) is obligatory within the scope of their authority.

Thus, the project- and task-oriented approaches gradually begin to displace traditional teaching methods. This also should include the "teaching to learn" concept. Hence it is necessary to develop students' self-study skills, and both students and teachers should become active and change their methods of work for this.

The study of law requires active attention, diligence and hard work. Therefore, the most popular pedagogical techniques are those which allow creating conditions that enhance the cognitive activity of students, developing independence, initiative, as "the key mechanism that triggers the process of personality development is the mechanism of self-organization" [9, p. 78].

One of such technologies is the technology of "flipped learning" (or "inverted classroom" - peer instruction). It "reverses" the process of learning so that students study the theoretical material independently, and class time is used for the solution of practical tasks. Thus, the flipped learning is a pedagogical model in which typical flow of lectures and the organization of homework are reversed.

According to Eric Mazur, who was the first to suggest and explain the concept of flipped learning, the senior teaching staff of most universities where he made presentations of peer instruction, including Harvard, positively perceived a new educational model, and the method works well not only when studying the exact sciences, where there are objectively right and wrong answers, but in the process of studying humanities as well.

This technology is widely used in Monash University which is a member of the Group of Eight, an alliance of leading Australian universities recognized for their contribution to the development of teaching and research. A separate section is dedicated to this issue on the website of the University [10].

In India, where there is an insufficient number of teachers of Mathematics, Physics, Chemistry, also found a way to use peer instruction without the teacher with profound knowledge of the subject. Avanti is a non-profit organization established in 2010 , in order to provide affordable high-quality education for students who are in adverse conditions and seek to learn at best colleges in India. In this model, without knowledge of the subject, the social workers of Avanti promote the process of the discussion among students, using the approaches of conceptual video, group discussion, advice and methods of preliminary reading, conceptual tests, homework, and solution of some tasks by experts [11]. It turns out that the students teach one another, and their understanding of the subject matter is better. Unresolved issues are passed to the head office in New Delhi through a social worker. And thus, they have achieved significant results - one of 
the students was enrolled into the University of Massachusetts and received a full scholarship [4].

This form of active learning is currently being tested by the Department of Civil Law of the National University "Odessa Law Academy" under the guidance of professor Y. Kharitonov: so, in the near future, we might hear about the first results and achievements in this area of focus.

It is worth noting that flipped learning technology is more effective when used during lectures. Its significance lies in the ability to turn a large course based on lectures into something that feels like a seminar, which is more efficient.

The seminar will work for a small group of students, it is a way to involve everybody in the class in the activity at once, but it will only be relevant for quite a small group.

\section{Conclusion}

The results of the study prove that curricula should be aimed at developing critical thinking, communicative skills, creative ingenuity and interaction skills, as the ability to build interpersonal relationships is the most significant quality nowadays. The curricula need to be focused on the broader professional competences of future lawyers - epistemological, communicative, functional, personality, which are essential in the aspect of students' acquisition of professional skills.

With this in mind, an experimental version of the educational process, with the introduction of practical components focused on the formation of the leading competences of future lawyers, was developed. Within the framework of the experiment, during the two academic years, with the involvement of about 160 students, the methods of active learning were applied: technologies of

\section{REFERENCES}

1. Kotykova, O.M. The state of research of the development of higher legal education of an independent Ukraine. [Stan doslidzhennia rozvytku vyshhoi yurydychnoi osvity nezalezhnoi Ukrainy]. Retrieved from: http://journals.uran.ua/index.php/2411-

5991/article/download/61130/56825 [in Ukrainian].

2. Sushhenko, V.M. [Suchasni problemy reformuvannia yurydychnoi osvity $i$ nauky v Ukraini]. [Modern problems of reforming legal education and science in Ukraine]. Retrieved from: http://lib.chdu.edu.ua/pdf/naukpraci/politics/2007/69-5633.pdf [in Ukrainian].

3. Ivashkevych, I.V. (2017). Psykhologhichni chynnyky stanovlennia profesiinoi kompetentnosti maibutnikh yurystiv. [Psychological factors of the development of the professional competence of lawyers]. Extended abstract of candidate's thesis. Kiev [in Ukrainian].

4. Khaiden, B. The first gentleman of Minerva. [Pervyi kavaler minervy]. Retrieved from: professional simulation, the solution of specific situations and enactment of active roles were used.

On the basis of the developed method of professional competencies assessment, positive results of the applied learning technology have been obtained, namely a significant increase in the level of future lawyers' professional competence. The indicated data are the evidence of the effectiveness of the experimental educational process aimed at the formation of professional skills of future lawyers and the formation of their professional competence.

Taking into account the abovementioned, we suggest to bring the educational process of general theoretical and humanitarian courses into the field of professional training of lawyers by introducing new forms and methods of active learning with widespread use of the practical component, which is fully focused on the formation of the leading competences of future lawyers, namely: the use of professional simulation technology, solving specific situations, enacting active roles, the technology of flipped learning, etc.

These changes will provide more significant results in case of active involvement of practitioners in the educational process, in connection with which it is proposed to consolidate the imperative rules on the minimum number of (in percentage terms) lecturers-practitioners of legal universities.

However, it should be noted that changes in the educational process must be conducted gradually, moving from the content of a particular subject to the development of skills and personal qualities of students. It is difficult to abandon the usual disciplinary type of the educational process immediately, so it is better to move towards this gradually, adding a new method and technology of practical development of competencies at a time.

http://erazvitie.org/article/pervyj_kavaler_minervy [in Russian].

5. Yorke, M. (2006). Employability and higher education: what it is - what it is not. ESECT, Learning \& Employability. Retrieved from: https://www.heacademy.ac.uk/knowledge-

hub/employability-higher-education-what-it-what-it-not [in English].

6. Robinson Jacquelyn, P. (2000). What are employability skills? The Workplace, 3. (Volume I). Retrieved from: http://www.foretica.org/wpcontent/uploads/2016/01/employability-skills.pdf [in English].

7. Bila knygha z reformuvannia ukrainskoi yurydychnoi osvity [White Paper on the reform of Ukrainian legal education]. Retrieved from: http://zdr.knu.ua/images/2015/2015-06/26/Bila_knyga.pdf [in Ukrainian].

8. Khairutdinov, D. «Navyki XXI veka»: novaia realnost $v$ obrazovanii ["Skills of the XXI century»: a new reality in education]. Retrieved from 
http://erazvitie.org/article/navyki_xxi_veka_novaja_realn ost [in Russian].

9. Petrenko, M.A. (2009). Funktsii interaktivnogo zaniatiia [Functions of Interactive Lesson]. Izvestiia Iuzhnogo federalnogo universiteta. Pedagogicheskie nauki - Izvestiya Southern Federal University. Pedagogical sciences, 8, 78-84 [in Russian].

\section{ЛIТЕРАТУРА}

1. Котикова О.М. Стан дослідження розвитку вищої юридичної освіти незалежної України. [Електронний ресурс] / О.М. Котикова. - Режим доступу : http://journals.uran.ua/index.php/2411-

5991/article/download/61130/56825

2. Сущенко В.М. Сучасні проблеми реформування юридичної освіти і науки в Україні. [Електронний ресурс] / В.М. Сущенко. - Режим доступу : http://lib.chdu.edu.ua/pdf/naukpraci/politics/2007/69-5633.pdf

3. Івашкевич I.В. Психологічні чинники становлення професійної компетентності майбутніх юристів : автореф. дис. ... канд. юрид. наук : 19.00.07 / І.В. Івашкевич. - К., 2017. - 24 с.

4. Хайден Б. Первый кавалер минервы. [Електронний ресурс] / Б. Хайден. - Режим доступу : http://erazvitie.org/article/pervyj_kavaler_minervy

5. Yorke M. Employability and higher education: what it is - what it is not. [Електронний ресурс] / M. Yorke // ESECT, Learning \& Employability. - Series One, $2006 . \quad$ - 2 Режим доступу: http://www.employability.ed.ac.uk/documents/Staff/HEA Employability_in_HE(Is,Isnot).pdf

6. Robinson Jacquelyn P. What are employability skills? [Електронний pecypc] / Jacquelyn P. Robinson // The Workplace. - 2000. - Volume I, Issue 3. - The
10. Peer Instruction in the Humanities Project the Monash of University. Retrieved from http://artsonline.monash.edu.au/peer-instruction-in-thehumanities [in English].

11. Grade Level Content. Retrieved from: http://avantifellows.org/grade-level-content [in English].

Alabama Cooperative Extension System. - Режим доступу:

http://www.fremont.k12.ca.us/cms/lib04/CA01000848/Ce ntricity/Domain/189/e mployability-skills.pdf

7. Біла книга з реформування української юридичної освіти [Електронний ресурс]. - Режим доступу : $\quad$ http://zdr.knu.ua/images/2015/201506/26/Bila_knyga.pdf

8. Хайрутдинов Д. «Навыки XXI века»: новая реальность в образовании. [Електронний ресурс] / Д. Хайрутдинов. - Режим доступу: http://erazvitie.org/article/navyki_xxi_veka_novaja_realn ost

9. Петренко М.А. Функции интерактивного занятия / М.А. Петренко // Известия Южного федерального университета. Педагогические науки. 2009. - № 8. - C. 78-84.

10. Peer Instruction in the Humanities Project the Monash of University [Електронний pecypc]. - Режим доступу: http://artsonline.monash.edu.au/peerinstruction-in-the-humanities/

11. Grade Level Content [Електронний pecypc]. Режим доступу: http://avantifellows.org/grade-levelcontent/

Ірина Віталіївна Давидова, кандидат юридичних наук, доцент кафедри циивільного права, Національний університет "Одеська юридична академія», вул. Фонтанська дорога, 23, м. Одеса, Украӥна

\section{ЯК ПРАКТИЧНА СКЛАДОВА НАВЧАЛЬНОГО ПРОЦЕСУ ПІДВИЩУС ПРОФЕСІЙНУ КОМПЕТЕНТНІСТЬ МАЙБУТНІХ ЮРИСТІВ?}

Статтю присвячено дослідженню застосування інноваційних методів в організації навчального процесу студентів, а саме: ролі та місця практичної складової у формуванні професійної компетентності майбутніх юристів. За результатами дослідження встановлено, що навчальні програми необхідно орієнтувати на більш широкі професійні компетенції (функції) майбутніх юристів - гносеологічні, комунікативні, функціональні, особистісні, які відіграють головну формуючу роль в аспекті набуття студентами професійних навичок та становленні відповідної (професійної) компетентності. Підкреслено цінність практичної складової під час навчального процесу, яка полягає в тому, що з'являється можливість використовувати навчальний час для групових занять, де студенти можуть обговорити зміст лекції, перевірити свої знання і взаємодіяти один з одним в практичній діяльності. Представлено успішні приклади використання практичної складової у навчальному процесі для формування професійної компетентності у майбутніх юристів, що дозволяє більш продуктивно засвоювати та застосовувати знання, отримані під час лекцій, семінарів. Побудовано експериментальний варіант навчального процесу з широким впровадженням практичної складової, орієнтованої на формування провідних компетенцій майбутніх юристів. На підставі побудованої методики оцінки професійних компетенцій зафіксовано зростання рівня компетенцій майбутніх юристів. Отримання позитивних результатів стало можливим також завдяки участі у проведенні таких методів активного навчання саме практика, який в реальному житті брав участь у вирі- 
шенні спорів, має детальну інформацію про запропоновані ситуації та варіанти їх вирішення в реальності, що має неабияке значення для майбутніх правозастосовувачів юридичної сфери. Важливим напрямом у розвитку юридичної освіти в Україні на етапі їі входження до європейського освітнього простору є реформування самого навчального процесу, що буде стимулювати індивідуальну навчальну активність студентів, краще володіння юридичною технікою, технікою аргументації, здатність вирішувати окремі юридичні проблеми, казуси, знаходити альтернативні рішення тощо. За результатами апробації внесено конкретні пропозиції щодо модернізації навчального процесу у сферу професійної підготовки фахівців-юристів шляхом запровадження нових форм i методів активного навчання з широким використанням практичної складової, направленої на формування професійних компетенцій та відповідного становлення професійної компетентності.

Ключові слова: юридична освіта, реформування, навчальний процес, методи активного навчання, професійна компетентність.

Submitted on June, 16, 2017

Reviewed by Doctor of Pedagogy, prof. T. Osypova 